\title{
The survival of Aristotelianism in early English mercantilism: an illustration from the debate between Malynes and Misselden
}

\author{
JOOST W. HENGSTMENGEL \\ Tilburg University
}

\begin{abstract}
Handbooks of the history of economic thought typically assume a strict fault line between scholastic economics and mercantilism. Historically, the distinction between the two streams of thought was less evident-especially when it came to the style of argumentation, in which there is much continuity between the scholastic doctors and early mercantilists. However, although the latter did not employ the scholastic method, both traditions frequently called upon classical authorities to strengthen their arguments. What is striking is the high regard for Aristotle among the late-sixteenth and earlyseventeenth century English mercantilists. By way of illustration, this article reviews the surprising role of Aristotelian ideas, primarily from the Metaphysics and Physics, within the debate between Gerard Malynes and Edward Misselden on England's economics crisis.
\end{abstract}

Keywords: Aristotle, Aristotelianism, mercantilism, Malynes, Misselden

JEL Classification: B11, B31

\section{INTRODUCTION}

Of the handbooks on the history of economic thought that do pay attention to the 'prehistory' of economics, most assume a strict fault line between scholastic economics and mercantilism. Late medieval and early-modern economic thought literally comprise different chapters in the subject's history.

Of course, there are many good reasons for regarding these traditions separately. Anyone who has glanced at the economic writings from the successive periods is struck by manifest differences, which is

AUTHOR's NotE: Previous versions of this paper were discussed in Rotterdam at the 2013 OZSW conference and a PhD seminar at the Erasmus Institute for Philosophy and Economics in November 2013. I would like to thank the audiences of both events and three anonymous referees for their helpful comments. 
revealed both in their content and their modes of presentation. As parts of voluminous theological and legal works written by university graduates, medieval economic discussions are full of erudite questions, objections, and metaphysical distinctions, and often refer to authorities from a distant past. Rather than being concerned with economic expediency, scholastic economic analyses were meant to offer moral guidance in microeconomic affairs. Mercantilist reasoning, by contrast, has come in the form of self-contained tracts and pamphlets, produced by lay writers to influence economic policy. Frequently prompted by threatened private interests, the focus is on particular economic problems at a national or international level. The descriptions of the economy put forward in these writings are mechanical and impersonal; they are much less concerned with morality than with material wealth. Finally, the scholastic method is absent, with the ideas contained therein presented in a more or less modern writing style. The products of scholastic economics and mercantilism thus are easily distinguishable.

Be this as it may, the distinction between the two streams of thought was historically speaking less evident. First, several early mercantilists of the sixteenth and seventeenth centuries were clearly influenced by medieval economic thought (De Roover 1955). Having consulted scholastic treatises, some mercantilist writings simply echoed the schoolmen's ideas about money and trade-albeit, they did so using a modernized vocabulary and applied these ideas to new contexts. The scholastic influence is best evinced by the works of Gerard Malynes, a transitional figure who, despite his frequent allusions to the teachings of the scholastic doctors, within the secondary literature is invariably counted among the mercantilists (cf. De Roover 1974). Second, the scholastic economic tradition survived far beyond what is traditionally regarded as the terminal point of the Middle Ages (Grice-Hutchinson 1952; 1978; 1993). After the fifteenth century, scholastic treatises dealing with economic questions continued to be published for at least another century and a half; in Spain and Italy 'economic scholasticism' continued to flourish in the hands of theologians and jurists. The teachings of the scholastics on subjects such as money, banking, and foreign exchange were disseminated with little modification and were used to solve the problems of the modern economic world.

Interestingly, also when it came to argumentation style there was a greater continuity than is often acknowledged. For instance, both doctors of the church and the early mercantilists made frequent appeals 
to classical authorities in support of their arguments. Instead of completely breaking with the past, many early modern pamphleteers "continued to venerate old saints", as expressed by Raymond de Roover (1949, 286). Influenced by the humanist spirit of the times, they even broadened the economic intellectual horizon by adding a whole range of Platonic and Stoic authorities to the traditional Aristotelian arsenal. Among the early mercantilists, a writer like Tobias Gentleman stands out as an exemplar for his self-proclaimed lack of erudition. The son of a fisherman, he admits in his England vvay to vvin wealth that "I am more skilfull in nets, lines, and hookes, then in rethoricke, logicke, or learned bookes" $(1614,3)$. Save for a mention of the ancient king Artaxerxes, the text indeed lacks any references or allusions to premodern wisdom. The writings of many of his mercantilist contemporaries, in contrast, abound with scholarship and learnedness.

Philosophers such as Aristotle, Plato (the "diuine Philosopher, and most Christian writer"), ${ }^{1}$ and Seneca, poets like Virgil and Horace, and orators like Cicero are a few examples of the authorities that were frequently cited to decorate or strengthen the main line of argument. For instance, the author of A discourse vppon usurye, Dr. Thomas Wilson (whom has been called a genuine schoolman), is known to have referred to the largest number of authorities in a single book. In a letter from the Bishop of Salisbury to Wilson, which was included in the book as advertisement, it is remarked that "suche weygte of reasons, suche examples of antiquitie, suche authority of doctours both Greekes and latines [...] suche learninge, suche eloquence, and so evident witnesse of gods holye wyl, can neuer possibly passe in vayne" (Wilson 1572, 'A letter founde'). In addition to countless references to Scripture, Wilson's dialogue is illuminated by a great number of opinions and quotations from ancient philosophers, Church Fathers, popes, scholastic doctors, and first-generation reformed theologians. To be clear, Wilson himself was not a theologian but a lawyer and government official.

A similar tendency to appeal to (classical) authorities can be observed in the writings of Malynes and Edward Misselden, together with Thomas Mun the key figures in early mercantilism. Judging from their writings, both merchants were well-versed in the classics, the schoolmen, and contemporary Renaissance thinkers alike (Finkelstein 2000a). Upon reading their pamphlets, one regularly encounters great

\footnotetext{
${ }^{1}$ Identical qualifications of Plato like this one from Wilson (1572, fol. 147a) can be found in W.S. $(1929,28,109)$ and Misselden $(1623,73)$.
} 
names like Herodotus, Plato, Aristotle, Seneca, Pliny, Plutarch, Virgil, Horace, and Aquinas, as well as modern writers like More, Bodin, and Grotius. Malynes, who is believed to be self-taught, drew from common and civil law, English histories, and modern scientific insights with the same ease. In one lengthy digression in his magnum opus-on the legendary philosopher's stone-he apologizes to his readers for the reason that the subject "which being farre from merchants profession, I hope shall not giue offence to the reader of this booke" (1622a, 258). A similar apology can be found in the second edition of one of the pamphlets of Misselden, whose education is unknown to us (though he sent his son to Emmanuel College in Cambridge). "Some men aske me", he writes in the introduction, "quorsum haec iactura? Wherefore all this cost and wast of learning \& languages, in the trodden way of trade? [...] as if it were not contingent to a merchant, to be acquainted with the muses" (1622, 'To the reader'). For the sake of illustration, he insists, "learning and languages are an appendix not unnecessary to the facultie of a merchant" (ibid.).

What is striking amidst all the displays of learnedness by Malynes and Misselden is their high regard for Aristotle, "the Philosopher" for the scholastics. Though they were far from the only writers to lean about the "sharpest philosopher of witt that there ever was"-as one sixteenth-century writer on economics had put it (W.S. 1929, 109)-the Greek philosopher plays a more significant role in their works than elsewhere. Malynes's observation that the Stagirite lived in the "infancy of traffique" (1622b, 38; 1622a, 316, 486) did not prevent either of them from presenting several Aristotelian ideas as truisms suitable for the modern commercial age. ${ }^{2}$ For example, Malynes time and again repeated Aristotle's distinction between natural and artificial riches (Politics $1256 \mathrm{a}$ ff.), and attached great importance to Aristotle's idea of money as mensura publica rather than a source of gain (Nicomachean ethics, 1133a7-b28; Politics, 1257a7-b17). He moreover stressed the necessity of distributive justice among members of a commonwealth and commutative justice in the commerce and traffic between nations (Nicomachean Ethics, V), two Aristotelian measures "ordained by God amongst men, to defend the feeble from the mightie" $(1603,2)$. Misselden, in turn, quoted the Philosopher in order to demonstrate that trade arose from the natural order of things (Politics, 1257a7-41) and is

\footnotetext{
${ }^{2}$ Various Aristotelian notions in Malynes and Misselden, including the idea of a "balance" of trade, are discussed in Finkelstein (2000a, chaps. 2, 3, 5).
} 
therefore pleasing to the creator. In searching for a definition of monopoly he mentions some of Aristotle's examples of this kind of restrain of the liberty of commerce (Politics, 1258b41-59a36).

In this article, the controversy between Malynes and Misselden and the role therein of Aristotelian ideas will be further reviewed. This specific case is meant to illustrate that, contrary to what is often suggested, not only the scholastics (to whom Aristotle was the economic authority par excellence) but also the early English mercantilists frequently reasoned from authorities like Aristotle. What is overlooked in the otherwise well-documented ${ }^{3}$ debate between the two is that Malynes and Misselden went beyond the Aristotelian commonplaces about money and trade just mentioned. Their theories were based not only on the Politics and Nicomachean ethics - two texts that formed the foundation of scholastic economics and remained influential well into the mercantilist age-but also on Aristotle's Metaphysics and Physics. Despite their fundamentally different economic outlooks, both writers adhered to an Aristotelian theory of causality and used Aristotle's doctrine of the four causes to analyse the nature of trade. Before discussing the role of these lesser-known Aristotelian ideas in the writings of Malynes and Misselden, I will first make some introductory remarks on the debate and the debaters more generally.

\section{THE OLD WORLDVIEW VERSUS THE NEW}

The debate between Malynes and Misselden took place in 1622 and 1623. Gerrard (or Gerard de) Malynes (fl. 1585-1626) was an Antwerpborn assay master at the mint and commissioner of trade, whereas Misselden (fl. 1615-1654) was a descendant of a family of Hackney merchants and prominent member of both the Merchant Adventurers' Company and East India Company. The debate resulted in four lengthy pamphlets. ${ }^{4}$ Though, in response to the acute economic crisis experienced

\footnotetext{
${ }^{3}$ Detailed accounts include Johnson (1937, chap. 4), Gould (1955), Supple (1959, chap. 9) and Muchmore (1969). See Elmslie (2015) for a recent study that discusses the influence of Malynes and Misselden among others.

${ }^{4}$ Incidentally, Mun also contributed to the debate on England's economic crisis. His $A$ discovrse of trade, from England vnto the East-Indies (1621) in defence of the East India Company does not explicitly refer to the writings of Malynes or any other author, and therefore will not be taken into account in this analysis. As one commentator rightly observed, Mun was a "merchant pure and simple, with no claim to scholarship" (Beer 1938, 147). It is only in his England's treasure by forraign trade, published posthumously, that Mun discussed the books of Malynes. "I find him skillful in many things which he hath both written and collected concerning th' affairs of merchants", he writes, "but where he hath disguised his own knowledge with sophistry to further
} 
by the English in the early 1620s, Misselden started the public quarrel by criticizing one of Malynes' treatises, which had been published as a report twenty years earlier for the government commission on foreign exchange. It is, Misselden claimed, as if Malynes tried to cure one economic disease with another, stating that, "contrary to our Saviours argument, that Satan cannot cast out Satan" (1622, 105-106). The disease with which Malynes was concerned in his early publications, and which remained central to the later debate, was England's chronic shortage of money. This problem was thought to be caused by an outflow of coin and specie, and had previously been attributed to either the low domestic prices, the decline of foreign trade, or the rise of unemployment.

Obviously of concern to both English writers, Malynes and Misselden profoundly disagreed about the underlying causes of the kingdom's "want of money". Given their different ideological premises and mutual accusations of ignorance and plagiarism, the polemic involved more than pure economic differences of opinion (Appleby 1978, chap. 2; Seligman 2000, 668-671). In possibly siding with Mun's verdict that Malynes was wrong, most commentators agree that Malynes held an "old" view concerning international economic affairs, while his opponent embodied a "new" one (Johnson 1933, 442). While these differences may have been exaggerated, the writers clearly had different economic outlooks: Malynes harkening back to the medieval world and Misselden anticipating a modern milieu. However, both men still agreed on the status of the king. As a representative of the almighty God, his duty was to watch over the welfare of the "microcosme" of the "great body politique" of the "weale publike" (Misselden 1622, 4). Next to increasing his own revenue, it was the duty of the king to promote the Christian religion and the material wealth of his subjects. Misselden defines the public good in terms of a flourishing trade, an improvement in navigation, and employment of the poor. Malynes, however, emphatically holds the monarch responsible for establishing economic justice and equality, consistent with the "lawe of God and Nature" (1603, 4). These typically medieval standards, which were based on book 5 of Aristotle's Nicomachean ethics, formed the basis of all Malynes' writings and marked a clear contrast with Misselden's more 'worldly' concerns.

some private ends by hurting the publick good; there ought he to be discovered and prevented" (1664, 109-110). 
The diverging worldviews of the two writers translated into what may be seen as technical disagreements about England's economic crisis. In summary, Malynes traced the source of all evil to the usurious behaviour of "bankers", i.e., people involved in foreign exchange. Instead of using bills of exchange (in the Aristotelian sense of public measure) between different countries, he argued that bankers abuse foreign exchange for their own gain. By the incorporation of usury, manipulation of the rate of exchange, and all kinds of speculative constructs, foreign exchange had become a merchandize itself. By controlling the exchange rate and systematically undervaluing the English coin (placing it below its par value as set by the mint), bankers were able to secure their own gains. It is this undervaluation, Malynes maintained, that caused the exportation and outflow of coin and specie. The only remedy was to restore the Royal Exchange in London, and to forbid all sales under the true value of exchange (par pro pari). Contrary to Malynes, Misselden claimed that the shortage of money was not caused by "merchandizing exchange", as his opponent called it, but by England's negative balance of trade. It was the consumption of luxury goods, importation of East-India stock, and exportation of low-value cloth, among others things, that restricted the inflow of money and induced its outflow. Whereas Malynes believed that the international course of commodities and money was overruled by foreign exchange, Misselden conceived of exchanges as something passive, the price of which was determined by laws of supply and demand.

The question of foreign exchange was one of the central concerns of early mercantilism as a whole (De Roover 1949). The malicious behaviour of bankers and exchange-dealers had already triggered some medieval commentators. Also in the second half of the sixteenth century several texts dealing with the issue were published. Building on these earlier writers, Malynes and Misselden proceeded from a similar strategy to resolve the nation's economic problems. Consistent with the intellectual fashion of their days, they conceived of the English commonwealth as a diseased body that could only be cured by administration of the right medicine. The medical terminology was first introduced by Malynes in his Treatise of the canker of Englands common wealth (1601b), where "canker" referred to an overbalance of foreign commodities with home commodities resulting in a decrease of wealth and exportation of money. According to the treatise's subtitle, "the author imitating the rule of good phisitions, first declareth the disease. 
Secondarily, sheweth the efficient cause thereof. Lastly, a remedy for the same". Before any remedy can be applied, the unknown disease of the "body politic" and its efficient cause must be diagnosed. Misselden in his first contribution similarly speaks of the "sicknesse of the trade", which if the causes are mistaken or remedies ill-applied, "may be brought from a disease in fieri to an habituated and in facto as the phisitians schoole hath it" $(1622,6)$.

\section{ARISTOTELIAN (META)PHYSICS}

Underlying Malynes's and Misselden's (then popular) medical approach is a highly mechanical theory of causation, one which was typical for this phase of mercantilism (Heckscher 1955, 308-316; Spiegel 1991, 96). Instead of being concerned with formulating ethical standards, as was the case with their predecessors, the economic pamphleteers explained the economy in terms of impersonal causes and effects. Often the belief in the existence of socio-economic causality was imbued with an emphasis on government intervention, by which the causes of economic ills could be identified and controlled. Sticking to this idea, the writings of Malynes and Misselden form a restless search for the true causes of England's economic crisis. It was thought to be effected, in the literal sense of the word, by prior flaws in the economic chain of events. In order to prevent these causes from exercising their harmful effects, they needed to be suppressed and removed through government intervention. Sublata causa, tollitur effectus, as can be read on the title page of Treatise of the canker. remove the cause and the effect will cease. The Latin phrase and its English rendering occur no less than six times in Malynes's writings ${ }^{5}$ and are explicitly presented as saying of "the Philosopher, [...] graffed in euery mans iudgement" (1601b, 3). The same saying is mentioned in Misselden's Free trade. It is of vital importance to inquire into the causes of the decay of trade, the author states, "for the causes being remoued, the effects must needs cease, according to the common maxime in philosophy, sublata causa tollitur effectus" (1622, 102).

\footnotetext{
${ }^{5} \mathrm{Cf}$. "the cause of any thing being taken away, the effect is taken away withall" (Malynes 1601b, 3; cf. 16); "take away the cause, and then the effect will cease" (1603, 93 [misnumbered]; cf. 156); "This cause being preuented, maketh the effect to cease; and this is engraffed in euery mans iudgement, according to the maxime often noted heretofore, sublata causa, tollitur effectus" (1622b, 14); "sublata causa, tollitur effectus" $(1623,50)$.
} 
Unfortunately, Malynes-the first to postulate it in the debate-did not provide a source for this maxim. It is likely, though, that he borrowed it from A compendious or briefe examination (1581), an early mercantilist dialogue that discusses enclosures, high prices, and international trade among many other economic subjects. In the dialogue, which is better known under the title of A discourse of the common weal of this realm of England, the maxim appears three times and is likewise presented as a saying of the Philosopher. With regard to the increasing dearness of things, it is remarked that, "for knowinge the occasion of the griefe, a man may soune avoyde the same occasion; and that beinge avoided, the greife is also taken awaye; for as the Philosopher saithe: Sublata causa tollitur effectus" (W.S. 1929, 97, cf. 99, $100,121)$. However interesting this earlier occurrence may be, Misselden's reference to a "common maxime" suggests a wider dissemination. A quick search through sixteenth-century sources indeed reveals many other applications, mostly in legal and theological contexts. An unexpected place where the same idea was voiced was sixteenth-century English drama (Dent 1984, 241). Sometimes the maxim was expressed in different terms, for example as ablata causa tollitur effectus, remota causa removetur effectus or, mainly in legal texts, as cessante causa cessat effectus. Focusing on the last-mentioned "celebrated proverb", the French jurist André Tiraqueau (Tiraquellus) in 1551 even published a book on civil law entitled Tractatvs cessante cavsa cessat effectvs. Hence, the use of the maxim was not limited to economic texts.

Even though in scholastic and humanist discourses "the Philosopher" almost invariably referred to Aristotle, it may of course be that the mercantilist writers used the phrase in a looser sense. The maxim would then be a common saying of philosophers in general. This impression is reinforced by the fact that the maxim, or any equivalent, cannot be traced in Aristotle's works. The closest to a credible source is an observation from Aristotle's Rhetoric (1400a25), that "if the cause is present, the effect is present, and if absent, absent. For cause and effect go together, and nothing can exist without a cause" (Aristotle 1984, 2231). But there is no mention here that in order to remove an effect, one must seek to remove the cause. Yet not only Malynes but also the anonymous author of the Discourse and another writer by the name of Richard Eburne $(1624,12)$ deliberately capitalized the term "Philosopher", thereby suggesting a connection to the Greek 
philosopher. And rightly so, because even if the phrase sublata causa tollitur effectus did not come from the pen of Aristotle himself, it is not farfetched to call it an Aristotelian maxim. ${ }^{6}$ The idea that an effect will cease when the cause is removed was one of the scholastic axioms of causality, which were based on and largely consistent with Aristotle's philosophy (Aveling 1909, 463; Söllner 1960, 187). ${ }^{7}$ The maxim is frequently mentioned, be it in alternative wordings, in commentaries on various works of the Philosopher, including Thomas Aquinas' Sententia metaphysicae (V, l. 3). In Aquinas' immensely influential Summa theologiae, the maxim occurs many times in one of the formulas mentioned before, for example, as one of the premises in his cosmological argument for the existence of a first cause (Summa Ia, q. 2, a. 3).

When the economic crisis is conceived of as an effect of one or more causes, Malynes observes, "the remedy is easie" (1601b, 99). Once the true causes have been successfully identified, it is up to the king to adopt the appropriate measures to take them away. The difficulty, however, is to discriminate between efficient and secondary causes. The "first and principall cause of putting forward all the rest afore him", Malynes argues, consistent with Aristotle's Metaphysics (1013a241014a25) and Physics (194b16-195b30), "[is] called causa efficiens, which not being rightly discerned from the meane causes, made that many men were neuer the neare to remedy the thing they went about" (1601b, 96). Alternatively, Misselden establishes that, although over time many causes of the decay of trade have been discussed and discoursed, the problem still awaits proper analysis. "To find out the causes of things", he believes, is no less than "a worke of philosophy" $(1622,6)$. The trade of the commonwealth can only be reformed if the crisis is first analyzed through "deformation" or decomposition into its constituent parts.

\footnotetext{
${ }^{6}$ There have been several attempts to pinpoint the origin of the maxim. Ultimately it can be traced back to Roman law (Krause 1960) and, as a basic philosophical principle, further to Aristotle's Physics and Posterior analytics (Gouron 1999). According to Krause, although during the Middle Ages the maxim was converted to a common rule, the "geistigen Hintergrund bildete Aristoteles" (1960, 86; cf. Nederman 1987, 33). Tiraqueau, a Renaissance writer sensitive to history, similarly believed that it had once been taken from book 2 of the Physics: "Estque ex lib. 2 Physicorum Aristotelis (ni fallor) deprompta" $(1559,8)$. A different, more recent suggestion that sublata causa is one of the medical aphorisms of Hippocrates (Forget 1854) is widespread but lacks an original source.

${ }^{7}$ The anonymous Policies to reduce this realme of Englande vnto a prosperus wealthe and estate (1549) speaks of "the moste aunctiente and trewe principle in phisike: cessant causa, cesset effectus [sic]" (Tawney \& Power 1924, 341).
} 
Whereas Malynes maintains that there are several accidental secondary causes and only one efficient cause, namely the "canker" of merchandizing exchange, Misselden's philosophical method yields a variety of causes believed to play a role. In addition to distinguishing between causes in matter and in form, he discusses respectively "immediate" and "mediate" (or remote) causes for the want of money and "deficient" and "efficient" causes of the decay of trade.

The Aristotelian method of decomposition employed by both authors was not new. Half a century before, the same strategy to find appropriate remedies for economic diseases had been proposed by the author of the Discourse of the common weal. In the opening pages of the third dialogue, which presented a remarkably detailed theory of causation for the time, it is explained that there are different sorts of causes. The causa sine quibus non, material and formal cause have to be distinguished from the efficient and principal cause "with oute removeinge of which cause the thinge can not be remedied" (W.S. 1929, 99). The point is that multiple effects may have one principal cause in common. Grievances like the general dearth, impoverishment, and the process of enclosure may be brought about by different secondary causes - which explains the existence of a great "diversitie of mens myndes and opinions" (W.S. 1929, 98) about the matter-but, in fact, have a shared first and original cause. The nature of reality, according to the author of the Discourse, works like a clock in which the first wheel drives the second $\operatorname{cog}$, the second $\operatorname{cog}$ the third, and so on until the last that drives the instrument that strikes the clock. ${ }^{8}$ In order to find out the efficient cause of one or more effects, all "meane" causes that are propelled by it need be left out of consideration. For only by identifying the efficient cause and stopping it from operating, the negative effects are definitively removed.

\section{ARISTOTELIAN PHYSICS}

Malynes' response to Misselden's Free trade, published several months later, was again framed in terms of Aristotelian causality (see 1622a, 110). The "moderne merchant of Hackney" (1622a, 9), by which he now denotes his opponent, failed to truly distinguish between efficient and secondary causes. Even though Misselden was right that the want for money is one of the secondary causes of the decay of trade, in actuality

\footnotetext{
${ }^{8}$ The same example was reproduced almost verbatim by Malynes in his Treatise of the canker (1601b, 95).
} 
this want was a direct consequence of the abuse of exchange. Furthermore, although the bartering, buying, and selling of commodities overseas was certainly part of the problem, what was ignored was the "mystery of exchange" (1622a, 'The epistle dedicatory'). Interestingly, from this point Malynes' arguments draw on book 3 of Aristotle's Physics. Commodities and money as such, we are told, are merely "things passive", the course of which is determined by the course of exchange, which is the efficient cause and the "thing active" (1622a, 6). Misselden, Malynes argues, is like a novice who, when conversing with another novice about the active causes of sailing, suggested that either the winds, the sails, or the compass is the most decisive. In reality, the efficient cause that makes a ship perform well is its rudder, the other causes such as the winds and sails being merely secondary.

In the chapters that follow, Malynes returns twice to the concepts of "activity" and "passivity" as developed in Aristotle's Physics. Somewhat confusingly, he now cites money, and not exchange, as the thing active. Further, he maintains that commodities are passive and that exchange determines both the flow of money and commodities (1622a, 15). According to Malynes, Misselden's theory became entangled since he failed to distinguish between the thing active and passive. Making his argument even more complicated, Malynes paraphrases Aristotle's idea from the Physics (202b11-14) that "action and passion" are merely relatives: each differing no more than the way from Thebes to Athens and from Athens to Thebes (1622a, 38). Does Malynes believe that commodities and money are so related that they are essentially the same $?^{9}$ This precisely is how Misselden interprets Malynes's train of thought in a counterattack that he published the year following. He accuses the "poore man [...] that hath neither wit nor art" of having misunderstood and abused Aristotle. Quoting from both the Greek philosopher and the Italian Julius Pacius (1550-1635), a contemporary Aristotle scholar and translator, Misselden explains that only "grosse ignorance" could lead one to adopt the view that Aristotle's philosophy permits seeing money and commodities as relatives or even the same thing $(1623,40-43)$.

\footnotetext{
${ }^{9}$ Note that the same obscure section can be found in Malynes's Consvetvdo (1622a, 486), but in a different context in which it is more sensible. It is possible that the author wrote it for his handbook ("the great whale") first, on which he was working while publishing his treatise ("the little fish") The maintenance of free trade (see 1622b, 'The epistle dedicatory').
} 
Earlier in his The circle of commerce, Misselden already had expressed doubts about the intellectual capacities of his opponent. The first chapter opens with the following rhetorical question: "What hope can we haue of this mans treatise, when hee failes in his title?". In Misselden's view, Malynes erroneously referred to commodities, money, and the exchange of money by means of bills of exchange as the three essential parts of trade. As a matter of fact, of the four Aristotelian causes in nature, only the material and formal causes constitute an object's essence, leaving no room for a third factor. By treating commodities and money as the matter of trade and buying and selling as its form (cf. Misselden 1622, 6-7, 53), the exchange of money can only be an essential part of trade if it is understood as a merchandize (matter) or kind of buying and selling (form) itself. Misselden goes on to quote a section from Malynes' handbook Consvetvdo, vel lex mercatoria in which the author suggests that trade consists of three beings or "simples", since the essence of objects is not only determined by materia and forma but also deprivation, i.e., "an imperfection so conioyned to the matter, that without her, if she were separated, nothing would be ingendered" (1622a, 500; see Physics I, §7-9). Again, drawing from the Physics and the commentary by Pacius, Misselden $(1623,11)$ accuses Malynes of having confused the principles of natural things with their essence. It is true that Aristotle reduces the principles of natural things into matter, form, and privation, but he explicitly excludes privation from their being.

In Misselden's opinion, Malynes was not familiar with Aristotle's works anyway. In an ultimate attempt to prove the ignorance of his opponent, Misselden accuses him of not having read the primary texts of the Greek philosopher. Speaking about Malynes' interpretation of Aristotle, he sneers:

[...] as ill a sophister is Malynes, not to discerne privation from the essence of naturall or artificial things. Which he might haue better vnderstood, if he had beene able to consult with Aristotle, or any of his interpreters. But alas, how should hee vnderstand him or them, when hee cannot so much as translate a sentence of him out of Latin, much lesse out of the originall, into proper or significant words $(1623,12)$ ?

Malynes, in short, has "more skill in philomythy"-i.e., the love of legends and fables_-"then philosophy" $(1623,22)$, which is necessary to distinguish between the different kinds of causes. According to 
Misselden, even his illustration of such an easy and familiar thing as navigation was mistaken: it is not the rudder of the ship, as Malynes had argued, which is the efficient cause-or causa sine qua non-of sailing, but the winds that fill the ship's sails.

To my knowledge, Malynes' and Misselden's analyses of economic phenomena in terms of Aristotle's four causes were quite uncommon. Yet there were forerunners, both among the early mercantilists and the scholastic doctors. For example, Jean Buridan, a pupil of William of Ockham and teacher of Nicole Oresme, in an exercise of Aristotelian (meta)physics had analysed the nature of money in terms the four causes:

The material cause is what money is made of. [...] The final cause is that man, with money, can have these things which are necessary for life. The formal cause is the figure of money, and the sign of the weight of money of such value. The efficient cause is the Prince, who has the government of the city, or the community of the citizens (quoted in Lapidus 1997, 28).

While most scholastic writers on economics based their theories on Aristotle's Politics and Nicomachean ethics, Buridan in the fourteenth century was among the few who drew from his Physics.

A fine sixteenth-century illustration can be found in the Cvstvmers apology of Thomas Milles (1599). In this pamphlet that primarily attacks the Merchant Adventurers Company for undermining the English customs system, the author (himself a customs-officer) investigates "The cavse or ground, whence such duties growe and haue their first being. The matter what, and where vpon such duties growing are to be paide and taken. The persons, whome such duties either immediatly or by consequence touch and concerne. The forme how to collect such duties, fit and peculiar to the cause, matter, and persons" (1599, The state of the cvstvmes, unpaginated). The cause of duties, he explains in quite some detail, is traffic. The matter, that which duties are taken upon, is merchandize transported over sea and imported in the country. The form, finally, is the manner of collection fit to the matter and persons (the prince, merchants, and customs-officers) involved. Since "cvstvmes follow traffick as the effect doth the cavses" and costumes enrich the prince and the commonwealth, to promote a just international trade based on the rules of reciprocity and equity is crucial. "Al effects", Milles claims with a rule reminiscent of sublata 
causa tollitur effectus, "work only by \& liue or dy with their proper cavses".

\section{CONCLUDING REMARKS}

This article exposed the role of Aristotelian ideas, directly and indirectly derived from Aristotle's Metaphysics and Physics, with regard to the controversy between two of the best-known mercantilist writers, Malynes and Misselden. Commentators may be right that of the two, Malynes was most attracted to the "old" philosophy. As Andrea Finkelstein remarks, despite being a "voracious reader who sampled every school of thought his age had to offer", Malynes "remained at heart an Aristotelian" (2000b, 26).$^{10}$ Like scholastic economics, Malynes's work was still very much concerned with economic justice as an indispensable means to preserve the harmony of the commonwealth. In addition to his disgust for profit-driven foreign exchange, he also wrote extensively on the evils of usury. His early work Saint George for England, allegorically described quite characteristically features a dragon, "called foenus politicum, [whose] two wings are usura palliate and usura explicata, and his taile inconstant cambium" (1601a, "To the reader'), which brings inequality and deprives the prince of his wealth. ${ }^{11}$ Misselden, by contrast, altogether ignores the issue of justice. Well aware of the new economic reality of the modern age, he wanted to leave foreign exchanges alone and advocated (limited) freedom of international trade. Nevertheless, his theory of causality and discussions of matter, form, and essence are unmistakably Aristotelian. Apparently, Misselden's encounter with radical opposition to Aristotelianism by the "famous logician of France" Petrus Ramus $(1623,72)$ did not stop him from employing an Aristotelian framework (Magnusson 1994, 76).

The case of Malynes and Misselden, and the examples from other writers provided in this article, is evidence for the more general claim that Aristotelianism survived in early English mercantilism. The term 'Aristotelianism' should not be taken too literally, however. Whatever its exact definition, Malynes and Misselden were neither members of an Aristotelian school, nor followers of Aristotle, nor commentators on his oeuvre. They at most subscribed to his philosophy and drew inspiration

\footnotetext{
${ }^{10}$ Max Beer went even further by observing in Malynes' writings a "self-imposed mission to uphold and spread the principles laid down by Aristotle, [and] the Schoolmen" (1938, 146).

${ }^{11}$ On the literary background of this book, see Sandison (1943).
} 
from his works. In discussing the views of the mercantilists on the nature of money, Eli Heckscher (the author of the standard work on mercantilism) has rightly observed that "[a]lmost everything that they stated on the matter had age-old roots reaching back to Aristotle and the schoolmen, but what is important is that they held fast to it" (1955, 260). This article showed that the same was true for other subjects. Early mercantilists such as 'W.S.' (i.e., the author of the Discourse of the common weal), Milles, Malynes, and Misselden attached importance to what Aristotle had declared about causality and implemented his ideas in their discussions of trade and commerce. The Greek philosopher in post-medieval economic thought still figured as a viable authority.

In a sense this conclusion is not a surprising one. The early English mercantilists wrote in a period when the Aristotelian worldview still dominated knowledge and science. The works of Francis Bacon and René Descartes, which helped to pave the way for a revolution in natural philosophy and economic thought alike (Letwin 1963; Webster 1975; cf. Leng 2014), were either not yet published or still had yet to gain momentum. All the same, the Aristotelian preoccupation of some early pamphleteers calls into question an all-too strict demarcation between mercantilism and scholastic economics as presented in some handbooks on the history of economic thought. Particularly with respect to argumentation style, both the scholastics and early mercantilists wrote in a vocabulary that gathered inspiration from Aristotle. To suggest, therefore, that only the former reasoned from authorities and the latter were empirically-minded, or to assume that scholastic influences were only present in the School of Salamanca, is historically inaccurate. The debate between Malynes and Misselden exemplifies that Aristotle's philosophy, which was once so fundamental to scholastic reasoning, was far from played out in the early years of mercantilism. An interesting thing is that they not only borrowed from Politics and Ethics, but also from Metaphysics and Physics.

\section{REFERENCES}

Appleby, Joyce O. 1978. Economic thought and ideology in seventeenth-century England. Princeton: Princeton University Press.

Aristotle. 1984. Rhetoric. In The complete works of Aristotle: the revised Oxford translation, ed. Jonathan Barnes. Princeton: Princeton University Press, vol. 2: 2152-2269. 
Aveling, Francis. 1908. Cause. In The Catholic encyclopedia, eds. Charles. G. Herbermann, Edward A. Pace, Condé B. Pallen, Rev. Thomas J. Shahan, Rev. John J. Wynne., New York: Robert Appleton Company, vol. 3: 459-467.

Beer, Max. 1938. Early British economics from the XIIIth to the middle of the XVIIIth century. London: George Allen \& Unwin.

Brown, Elizabeth A.R. 1972. Cessante causa and the taxes of the last Capetians: the political applications of a philosophical maxim. Studia Gratiana, 15: 567-587.

Dent, Robert W. 1984. Proverbial language in English drama exclusive of Shakespeare, 1495-1616: an index. Berkeley, Los Angeles, London: University of California Press.

Eburne, Richard. 1624. Plaine path-vvay to plantions: that is, a discourse in generall, concerning the plantation of our English people in other countries. [London].

Elmslie, Bruce. 2015. Early English mercantilists and the support of liberal institutions. History of Political Economy, 47 (3): 419-448.

Finkelstein, Andrea. 2000a. Gerard de Malynes and Edward Misselden: the learned library of the seventeenth-century merchant. Book History, 3 (1): 1-20.

Finkelstein, Andrea. 2000b. Harmony and the balance: an intellectual history of seventeenth-century English economic thought. Ann Arbor: University of Michigan Press.Forget, [Charles-Polydore]. 1854. Examen de l'aphorisme: sublata causa tollitur effectus. Paris: Félix Malteste.

Gentleman, Tobias. 1614. England vvay to vvin wealth, and to employ ships and marriners. London.

Gould, J.D. 1955. The trade crisis of the early 1620s and English economic thought. The Journal of Economic History, 15 (2): 121-133.

Gouron, André. 1999. Cessante causa cessat effectus: à la naissance de l'adage. Comptes rendus des séances de l'Académie des Inscriptions et Belles-Lettres, 143 (1): 299-309.

Grice-Hutchinson, Marjorie. 1952. The School of Salamanca: readings in Spanish monetary theory 1544-1605. Oxford: Clarendon Press.

Grice-Hutchinson, Marjorie. 1978. Early economic thought in Spain 1177-1740. London: George Allen \& Unwin.

Grice-Hutchinson, Marjorie. 1993. Economic thought in Spain: selected essays of Marjorie Grice-Hutchinson. Aldershot: Edward Elgar.

Heckscher, Eli F. 1955. Mercantilism. 2nd ed. London: George Allen \& Unwin / The Macmillan Company.

Johnson, E.A.J. 1933. Gerard de Malynes and the theory of the foreign exchanges. American Economic Review, 23 (3): 441-455.

Johnson, E.A.J. 1937. Predecessors of Adam Smith. New York: A.M. Kelly.

Krause, Hermann. 1960. Cessante causa cessat lex. Zeitschrift der Savigny-Stiftung für Rechtsgeschichte: Kanonistische Abteilung, 46 (1): 81-111.

Lapidus, André. 1997. Metal, money, and the prince: John Buridan and Nicholas Oresme after Thomas Aquinas. History of Political Economy, 29 (1): 21-53.

Leng, Thomas. 2014. Epistemology: expertise and knowledge in the world of commerce. In Mercantilism reimagined: political economy in early modern Britain and its empire, eds. Philip J. Stern and Carl Wennerlind. Oxford: Oxford University Press, 97-116.

Letwin, William. 1963. The origins of scientific economics: English economic thought 1660-1776. London: Methuen. 
Magnusson, Lars. 1994. Mercantilism: the shaping of an economic language. London: Routledge.

Malynes, Gerard. 1601a. Saint George for England: allegorically described. London.

Malynes, Gerard. 1601b. A treatise of the canker of Englands Common Wealth. London.

Malynes, Gerard. 1603. Englands vievv, in the vnmasking of two paradoxes: with a replication vnto the answer of maister Iohn Bodine. London.

Malynes, Gerard. 1622a. Consvetvdo, vel lex mercatoria, or the ancient law-merchant. London.

Malynes, Gerard. 1622b. The maintenance of free trade, according to the three essentiall parts of traffique. London.Malynes, Gerard. 1623. The center of the circle of commerce. Or, a refutation of a treatise, intituled the circle of commerce, or the ballance of trade, lately published by E.M. London.

Milles, Thomas. 1599. The cvstvmers apology. [London?].

Misselden, Edward. 1622. Free trade. Or, the meanes to make trade florish. 2nd ed. London.

Misselden, Edward. 1623. The circle of commerce. Or the ballance of trade, in defence of free trade. London.

Muchmore, Lynn. 1969. Gerrard de Malynes and mercantile economics. History of Political Economy, 1 (2): 336-358.

Mun, Thomas. 1664. England's treasure by forraign trade. Or, the balance of our forraign trade is the rule of our treasure. London.

Nederman, Cary J. 1987. Aristotle as authority: alternative Aristotelian sources of late mediaeval political theory. History of European Ideas, 8 (1): 31-44.

Roover, Raymond de. 1949. Gresham on foreign exchange: an essay on early English mercantilism. Cambridge (MA): Harvard University Press.

Roover, Raymond de. 1955. Scholastic economics: survival and lasting influence from the sixteenth century to Adam Smith. Quarterly Journal of Economics, 69 (2): 161190.Roover, Raymond de. 1974. Gerrard de Malynes as an economic writer: from scholasticism to mercantilism. In Business, banking, and economic thought in late medieval and early modern Europe: selected studies of Raymond de Roover, ed. Julius Kirschner. Chicago : University of Chicago Press, 346-366.

Sandison, Helen E. 1943. An Elizabethan economist's method of literary composition. Huntington Library Quarterly, 6 (2): 205-211.

Seligman, Edwin R.A. 2000. Curiosities of early economic literature. History of Political Economy, 32 (3): 659-691.

Söllner, Alfred. 1960. Die Causa im Kondiktionen-und Vertragsrecht des Mittelalters bei den Glossatoren, Kommentatoren und Kanonisten. Zeitschrift der SavignyStiftung für Rechtsgeschichte: Romanistische Abteilung, 77 (1): 182-269.

Spiegel, Henry W. 1991. The growth of economic thought. 3rd ed. Durham (NC): Duke University Press.

Supply, B.E. 1959. Commercial crisis and change in England 1600-1642: a study in the instability of a mercantile economy. Cambridge: Cambridge University Press.

Tawney, R.H., and Eileen Power. 1924. Tudor economic documents. Volume three. Pamphlets, memoranda, and literary extracts. London: Longmans.

Tiraqueau, André. 1559. Tractatvs, cessante cavsa cessat effectvs. 3rd ed. Lyon.

W.S. 1581. A compendious or briefe examination of certayne ordinary complaints of diuers of our country men in these our dayes. London. 
W.S. 1929. A discourse of the common weal of this realm of England, ed. Elizabeth Lamond. Cambridge: Cambridge University Press.

Webster, Charles. 1975. The great instauration: science, medicine and reform 16261660. London: Duckworth.

Wilson, Thomas. 1572. A discourse vppon usurye, by vvaye of dialogue and oracions. [London?].

Joost W. Hengstmengel is a post-doctoral researcher at the Tilburg School of Catholic Theology, Tilburg University, the Netherlands. In 2015 he completed his $\mathrm{PhD}$ thesis Divine oeconomy: the role of Providence in early-modern economic thought before Adam Smith. His research interests include the history of pre-modern economic thought and the relationship between economics and theology. Contact e-mail: <j.w.hengstmengel@uvt.nl> 